DOI 10.4467/2543733XSSB.21.019.13812

\author{
KATARZYNA FIJOŁEK-KWAŚNIEWSKA
}

Instytut Nauk Politycznych i Stosunków Międzynarodowych

Uniwersytet Jagielloński w Krakowie

\title{
PARTIE TWORZĄCE KOALICJĘ ZJEDNOCZONYCH PATRIOTÓW (2016-2019) WOBEC MNIEJSZOŚCI TURECKIEJ I REPUBLIKI TURCJI
}

\author{
Parties of the United Patriots' Coalition (2016-2019) \\ and their Narrative Towards \\ the Turkish Minority in Bulgaria and the Republic of Turkey
}

Summary

The aim of this paper is to identify the individual political elements of the United Patriots' coalition. The nationalist electoral alliance formed in 2016 by Attack, the IMRO-Bulgarian National Movement and National Front for the Salvation of Bulgaria took a part of the third Boyko Borissov government. Starting this new partnership with the populist radical right, the GERB has resigned from promoting EU values, including minorities' rights, much more than before. This coalition established xenophobia and making racists statements as a standard of Bulgarian parliamentary discussion. Its attitude towards the Turkish minority in Bulgaria and the Republic of Turkey shows hostility and prejudice.

Key words: Turkish minority, Republic of Bulgaria, Republic of Turkey, Bulgarian populist radical right, Bulgarian nationalism

Słowa kluczowe: mniejszość turecka, Republika Bułgarii, Republika Turcji, bułgarska populistyczna skrajna prawica, bułgarski nacjonalizm

W dniu 4 maja 2017 r. premier Bojko Borisow (bułg. Бойко Борисов) powołał swój trzeci gabinet. Obok zwycięskiej partii GERB ${ }^{1}$, jego skład reprezentowali politycy koalicji

\footnotetext{
${ }^{1}$ GERB - Obywatele dla Europejskiego Rozwoju Bułgarii, bułg. Граждани за европейско развитие на България, ГЕРБ.
} 
„Zjednoczeni Patrioci”2. Jej przedstawiciele otrzymali cztery resorty, a o wysokim znaczeniu koalicyjnego partnerstwa świadczył fakt, że zarówno Krasimir Karakaczanow (bułg. Красимир Каракачанов), jak i Waleri Simeonow (bułg. Валери Симеонов) - czołowi działacze OP - objęli funkcję wicepremierów. Karakaczanow został ponadto mianowany ministrem obrony, zaś Simeonow miał odpowiadać za politykę gospodarczą i demograficzną․ W XLIV Zgromadzeniu Narodowym (bułg. Народно събрание, HC, pl. NS) grupa OP liczyła łącznie 27 deputowanych.

Przez kolejne dekady od 1989 r. postępowało stopniowe rozwarstwienie bułgarskiej sceny politycznej. W następstwie niepełnej przewagi partia rządząca zdecydowała się na sojusz z ugrupowaniami, które dotychczas egzystowały obok głównego nurtu polityki. Nowy układ sił politycznych w połowie miały reprezentować populistyczne partie skrajnej prawicy, które dotychczas identyfikowały się jako antysystemowe. Nie bez znaczenia pozostawał także ich bezkompromisowy stosunek wobec mniejszości etnicznych zamieszkujących Bułgarię. Historia zawiązania koalicji przez wspomniane trzy ugrupowania zaczęła się krótko przed wyborami prezydenckimi w 2017 r. Dnia 28 czerwca 2016 r. partia polityczna ATAKA ${ }^{4}$, Narodowy Front Ocalenia Bułgarii ${ }^{5}$ oraz Wewnętrzna Macedońska Organizacja Rewolucyjna - Bułgarski Ruch Narodowy ${ }^{6}$ uzgodniły wspólnego kandydata na urząd prezydenta. Został nim Karakaczanow, który w rezultacie znalazł się tuż poza drugą tura, uzyskując 14,97\% poparcia ${ }^{7}$. W wyniku wyborów, które wygrał Rumen Radew (bułg. Румен Радев), Bojko Borisow zdecydował o dymisji rządu. Traktując to jako impuls do dalszego działania, ATAKA, WMRO-BND i NFSB zgłosiły do Centralnej Komisji Wyborczej 30 września 2016 r. swój udział w przedterminowych wyborach parlamentarnych pod szyldem koalicji „Zjednoczonych Patriotów”. Mówiąc o porozumieniu, warto podkreślić, że chociaż trzy partie łączyła większość kwestii ideologicznych, przez lata rywalizowały o ten sam elektorat, czyli o głosy wyborców rozczarowanych dotychczasowym podziałem dwubiegunowym.

W latach 1989-2001 parlamentaryzm w Bułgarii charakteryzował się dychotomicznym podziałem na socjalistów, którzy przejęli sukcesję po $\mathrm{BKP}^{9}$, oraz dawną opozycję skupioną wokół Związku Sił Demokratycznych ${ }^{10}$. Do 2001 r., czyli do momentu pojawienia się NDSW ${ }^{11}$, bułgarski elektorat posiadał dość wąski wybór formacji, które liczyłyby się w wyścigu wyborczym. Stronnictwa o profilu nacjonalistycznym czy też skrajnie lewicowe zdobywały poparcie na poziomie odległym od czteroprocentowego progu wyborczego.

\footnotetext{
${ }^{2}$ Koalicja „Zjednoczeni Patrioci”- bułg. Обединени патриоти, OП, pl. OP.

${ }^{3}$ Решение за избиране на Министерски съвет на Република България, ДВ бр. 37, 09.05.2017, s. 3.

${ }^{4}$ Partia polityczna ATAKA - bułg. Политическа партия „ATAKA”.

${ }_{5}^{5}$ Narodowy Front Ocalenia Bułgarii - bułg. Национален фронт за спасение на България, НФСБ, pl. NFSB.

${ }^{6}$ Wewnętrzna Macedońska Organizacja Rewolucyjna - Bułgarski Ruch Narodowy - bułg. Вътрешна македонска революционна организация - Българско национално движение, BMPO-БНД, pl. WMRO-BND.

${ }^{7}$ ЦИК, Резултати от избори за президент и вицепрезидент на Републиката и Национален Референдум 2016, https://results.cik.bg/pvrnr2016/tur1/president/index.html, (dostęp: 14.05.2020).

${ }^{8}$ Коалицйа Обединени патриоти, Официална уеб страница на Обединени патриоти, http:// obedinenipatrioti.com/\%d0\%ba $\% \mathrm{~d} 0 \%$ be $\% \mathrm{~d} 0 \% \mathrm{~b} 0 \% \mathrm{~d} 0 \% \mathrm{bb} \% \mathrm{~d} 0 \% \mathrm{~b} 8 \% \mathrm{~d} 1 \% 86 \% \mathrm{~d} 0 \% \mathrm{~b} 8 \% \mathrm{~d} 1 \% 8 \mathrm{f} /$, (dostep, 04.06.2020).

${ }^{9}$ BKP - Bułgarska Partia Komunistyczna, bułg. Българска комунистическа партия, БКП.

${ }^{10}$ Związek Sił Demokratycznych, bułg. Съюз на демократичните сили, СДС, pl. SDS.

${ }^{11}$ NDSW - Narodowy Ruch Symeona II, bułg. Национално движение Симеон II, НДСВ.
} 
Trudno wskazać jednolitą przyczynę, która wpłynęła na umocnienie ugrupowań populistycznej skrajnej prawicy. Jak wskazuje Czolakow, nastąpiło to w momencie, gdy skompromitowany rząd Symeona Sakskoburggotskiego tracił poparcie społeczne. Partnerem koalicyjnym NDSW był wówczas Ruch na rzecz Praw i Swobód ${ }^{12}$, partia założona jeszcze w 1990 r. przez bułgarskich Turków. Nieudolność rządów NDSW obdarzonego początkowo ogromnym mandatem zaufania społecznego, mniejszości etniczne aktywnie sprawujące władzę oraz afery finansowe zapoczątkowały ruch w stronę radykalizacji ${ }^{13}$. Sformowanie koalicji Narodowego Zjednoczenia ATAKA (2005) nie wystarczyło jednak, aby sprawować władzę. Potrzeba było kolejnej dekady, aby połączone siły bułgarskiej prawicy realnie wzięły udział w procesie rządzenia. Jednakże zawarty w 2016 r. pakt nie należał do najtrwalszych, bowiem trzy lata później WMRO-BND i NFSB oddzieliły się od ATAKI ${ }^{14}$.

Celem tego artykułu jest uwypuklenie, w jaki sposób partie koalicji OP postrzegają mniejszość turecką w Bułgarii oraz kraj odgrywający rolę zagranicznej ojczyzny dla tej mniejszości ${ }^{15}$, czyli Republikę Turcji. Aby odpowiedzieć na to pytanie, warto najpierw scharakteryzować sam termin ,populistyczna skrajna prawica” (ang. populist radical right), który uznano za najbardziej trafny w odniesieniu do tych trzech podmiotów.

Biorąc pod uwagę różnorodność definicji i nomenklatury, które stosują badacze, opisując partie skrajnej prawicy (ang. right-wing parties, far right parties, radical right parties, nationalist parties), niezwykle trudno dobrać zestaw kryteriów, które klarownie zidentyfikowałyby profil tych jednostek politycznych. Dodatkową trudność powoduje obszerne zastosowanie nazewnictwa nie tylko do celów naukowych, ale także w przestrzeni publicznej ${ }^{16}$. Na potrzeby tego artykułu autorka odniesie się do zaproponowanego przez Casa Mudde terminu - populistyczna skrajna prawica (ang. populist radical right, PRR). Trafnie wyraża on współczesne trendy obecne wśród tej rodziny partyjnej (ang. party family), jednocześnie separując od kontekstu „dawnej” skrajnej prawicy ${ }^{17}$. Mudde zauważa, że pośród różnorodnych atrybutów, które opisują partie populistycznej skrajnej prawicy, najczęściej spotykane to: autorytaryzm, populizm i natywizm ${ }^{18}$. Autorytaryzm dotyczy przywiązania do porządku społecznego. Nieprzypadkowo retoryka PRR opiera się na krytyce i punktowaniu słabości ładu demokratycznego. Celem powinno być budowanie silnego państwa, w którym dominującą rolę będzie odgrywać prawo i porządek. Kolejna cecha, populizm, odzwierciedla raczej styl prowadzenia polityki, odnosi się bowiem do tworzenia podziałów pomiędzy „,dobrymi obywatelami” a elitami, czy też innymi uprzywilejowanymi grupami (w sensie ekonomicznym, kulturowym, politycznym, etc.). Natomiast natywizm wiąże się z poczuciem obowiązku ochrony narodu oraz jego dziedzictwa

${ }^{12}$ Ruch na rzecz Praw i Swobód - bułg. Движение за права и свободи, ДПC, pl. DPS.

${ }^{13}$ P. Cholakov, Ethnic entrepreneurs unmasked, 2018, s. 112-113.

14 „Обединени патриоти” се разиепиха: ВМРО и НФСБ изключиха АТАКА, portal Mediapool.bg, 25.06.2019, https://www.mediapool.bg/obedineni-patrioti-se-raztsepiha-vmro-i-nfsb-izklyuchiha-atakanews296166.html, (dostęp: 04.06.2020).

${ }^{15}$ Republika Turcji, Republika Bułgarii oraz mniejszość turecka ją zamieszkująca tworzą wzorcowy przykład tzw. potrójnego ogniwa (ang. triadic nexus), o którym pisze Rogers Brubaker, zob. R. Brubaker, Nacjonalizm inaczej. Struktura narodowa i kwestie narodowe w nowej Europie, Warszawa 1998, s. 70-89.

${ }^{16} \mathrm{C}$. Mudde, The ideology of the extreme right, Manchester 2002, s. 10.

${ }^{17}$ Kryteria rozróżnienia „,nowej” i „starej” skrajnej prawicy proponuje m.in. Ignazi, zob. P. Ignazi, The silent counter-revolution, „European Journal of Political Research”, 22, 2006.

${ }^{18}$ C. Mudde, Populist radical right parties in Europe, Cambridge 2007, s. 26. 
przed innymi nacjami oraz ich wpływem kulturowym ${ }^{19}$. Poniższa analiza koncentruje się na ideologicznej sferze funkcjonowania trzech partii w ramach aliansu Zjednoczonych Patriotów oraz ich stosunku wobec mniejszości tureckiej i sąsiedniej Republiki Turcji.

Pierwsza z partii, ATAKA, pojawiła się w życiu politycznym w 2005 r., a zatem tuż przed wejściem Bułgarii do Unii Europejskiej. Będąc właściwie koalicją partii ${ }^{20}$ kierowanych przez aktywistę i dziennikarza - Wolena Siderowa (bułg. Волен Сидеров), okazała się wyborczą sensacją. Zdobywszy 8,93\% głosów, ATAKA miała być reprezentowana przez 21 deputowanych ${ }^{21}$. Socjaliści, którzy uzyskali wtedy przewagę $(33,98 \%)$, nie zaprosili do rozmów tego ugrupowania ${ }^{22}$. Paradoksalnie to jeszcze bardziej pomogło debiutującej formacji. Z parlamentarnych ław jako opozycja, posłowie ATAKI mogli budować swoje poparcie, bezlitośnie podważając autorytet koalicji rządzącej. Świadczy o tym poniższe wystąpienie Siderowa, które miało miejsce jeszcze przed powołaniem nowego rządu:

[...] Koledzy, Bułgarzy! Jestem przekonany, że gdy bułgarscy wyborcy głosowali 25 czerwca, nie przypuszczali, jaki polityczny Frankenstein narodzi się zaledwie miesiąc po ich wyborze. Nie przypuszczali, że pewna etniczna antykonstytucyjna turecka partia wskoczy im na głowę i udusi ich w swoim uścisku. Nie myśleli o tym ci zrozpaczeni, ci bezrobotni, ci zdesperowani Bułgarzy z regionów Kyrdżali, Razgradu, Tyrgowiszte, Szumenu, którzy już nie mogą nazywać się Bułgarami i nie mogą mówić po bułgarsku. Nie przypuszczali, że następcy pewnej terrorystycznej organizacji, [...] która zabiła kobiety i dzieci na dworcu w Bunowie, obecnie będą rządzić Bułgarią, dzierżąc ponad 50\% władzy wykonawczej. Tego miliony Bułgarów nie mogą pojać! Tego miliony Bułgarów nie pojmą! Tego my, bułgarscy nacjonaliści, nie przyjmujemy i mówimy kategoryczne „NIE”! [...] Zwracam się do wszystkich deputowanych, w których żyłach wciąż płynie bułgarska krew: nie popierajcie tego gabinetu, powiedzcie „NIE” temu antybułgarskiemu gabinetowi! Bułgaria ponad wszystko! Bułgaria dla Bułgarów! ${ }^{23}$

Wątek etniczny odgrywa przemożną rolę w ideologii ATAKI. W 2005 r., kiedy wstępowała ona na scenę polityczną, Ruch na rzecz Praw i Swobód trwał na niej niemal od

${ }^{19}$ C. Mudde, The ideology..., s. 170.

${ }^{20} \mathrm{Z}$ braku odpowiedniej dokumentacji, ATAKA w wyborach była zmuszona startować nie jako autonomiczna jednostka polityczna, ale koalicja pomniejszych partii nacjonalistycznych. Na mocy decyzji CIK z 11 maja 2005 r. zarejestrowano Koalicję Narodowego Zjednoczenia ATAKA (bułg. Коалиция Национално обединение „AТАКА”), [za:] ЦИК, Решение но 80 от 11 май, 2005 г., http://pi2005.cik.bg/reshenia/080.html, (dostęp: 07.06.2020).

${ }^{21}$ ЦИК, Резултатите от парламентарни избори 2005, http://pi2005.cik.bg/results/index.html, (dostęp: 07.06.2020).

${ }^{22}$ Ibidem, (dostęp: 07.06.2020).

${ }^{23}$ W oryginale: Колеги, българи! Аз съм сигурен, че когато българските избиратели гласуваха на 25 юни никога не са предполагали какъв политически Франкенщайн ще се роди само месец след вота им. Не са допускали, че една етническа турска антиконституционна партия ще им се качи на главата и ще ги задуши в прегръдките си. Това не са го мислили тези отчаяни, тези безработни, тези обезверени българи от районите в Кърджали, в Разград, в Търговище, Шумен, които вече не могат да се нарекат българи и не могат да говорят на български. Те не са предполагали, че наследниците на една терористична организация, [...] която убиваше жени и децฺа на гара Буново, сега щче управлява България с над 50\% от изпълнителната власт. Това милиони българи не могат да го приемат! Това милиони българи няма да приемат. Това ние, българските националисти, не приемаме и ще му кажем категорично “Не!”. [...] Обръщам се към всички депутати, в чиито вени тече българска кръв: не подкрепяйте този кабинет, кажете “не” на този антибългарски кабинет! България над всичко, България на българите! [za:] Стенограми от пленарни заседания на 40-то Народно събрание, 27.07.2005, https://parliament.bg/bg/plenaryst/ ns/2/ID/18, (dostęp: 27.04.2020). 
piętnastu lat. Od pierwszych demokratycznych wyborów w Bułgarii DPS nieprzerwanie funkcjonował w Zgromadzeniu Narodowym, a w ostatnich latach uczestniczył także w sprawowaniu władzy wykonawczej. Ta trwała obecność w polityce była określana przez Ahmeda Dogana, lidera DPS, jako realizacja „,bułgarskiego modelu etnicznego"24. DPS postrzegało siebie jako twórcę tej koncepcji pokojowego współistnienia etnosów w Bułgarii $^{25}$. To nie podobało się nacjonalistom, których burzliwy sprzeciw i teatralne przemówienia obserwował elektorat.

Reprezentując nurt kontestatorski, ATAKA bezkompromisowo punktowała dotychczasowe elity polityczne. Rozczarowani wyborcy, których poziom życia w przededniu wejścia do Unii Europejskiej nie uległ poprawie, wierzyli argumentom, że to „obcy” destabilizują Bułgarię. Obcym w języku ATAKI były grupy realizujące zewnętrzne układy gospodarcze, wielkie mocarstwa, ale także mniejszości zamieszkujące Republikę Bułgarii. Badania paryskiego CERSA ${ }^{26}$ wskazują, że statystycznie największe poparcie ATAKA notowała wśród średniej grupy wiekowej, mieszkańców niewielkich ośrodków miejskich o bułgarskiej przynależności etnicznej, ze średnim wykształceniem i aktywnych zawodowo. Według Frison-Roche'a elektorat tej partii w dużym stopniu wywodził się z byłych wyborców BSP, którzy stopniowo radykalizowali poglądy. W 2001 r. ta grupa chętnie popierała NDSW, a po klęsce ugrupowania Symeona II zradykalizowała się poglądowo jeszcze mocniej. Badacz nazwał to zjawisko nomadyzmem wyborczym ${ }^{27}$. Podatnym gruntem dla tych wyborców okazal się program polityczny partii ATAKA ${ }^{28}$, który podkreślat, że to interes narodowy będzie stał zawsze na pierwszym miejscu. Majac na myśli narodowy, formacja rozumiała interes bułgarski, a zatem promocję rodzimej kultury i tradycji, wspieranie lokalnych przedsiębiorców, prymat wyznaniowy Cerkwi Prawosławnej i jej wpływ na życie polityczne, specjalny status języka bułgarskiego, zakaz sprzedaży ziemi cudzoziemcom, etc $^{29}$. Niewłaściwe byłoby sugerować, że Wolen Siderow i jego współpracownicy negowali istnienie innych grup etnicznych. Niemniej w ich wizji państwa wszystkie działania i prowadzona polityka miały być nakierowane na umocnienie narodu bułgarskiego oraz kultury, którą reprezentował. Rogers Brubaker, pisząc o państwie zorientowanym narodowo, charakteryzował jego politykę etniczną dwoma tendencjami. Pierwsza z nich określała poczucie „własności”, czy też posiadania państwa przez konkretną grupę, która zazwyczaj nie występuje w imieniu ogółu populacji. Druga opisywała użycie władzy państwowej, aby umacniać i chronić interesy nacji postrzegającej się jako rdzenna ${ }^{30}$. Takie podejście promowała ATAKA, co potwierdza sztandarowy dokument partii - 20 punktów. Wśród nich znajdują się bezpośrednie odniesienia i rozwiązania w kwestii polityki etnicznej:

${ }^{24}$ Zob. A. Доган, По образ и подобие на европейските измериния. Избрани речи на Ахмед Доган 1990-2008, Sofia 2009.

${ }^{25}$ Więcej o koncepcji tzw. bułgarskiego modelu etnicznego - zob. М. Мизов, Българският етнически модел. Политическа митологема или проблемна реалност?, Sofia 2011.

${ }^{26}$ CERSA - pl. Centrum Studiów i Badań Nauk Administracyjnych i Politycznych.

${ }^{27}$ F. Frison-Roche, Bulgarie: sociologie électorale d'Ataka, nouveau parti dans l'arène politique bulgare (2005), CERSA, 07.02.2012, https://www.colisee.org/old/public//article/fiche/1935, (dostęp: 07.06.2020).

${ }^{28}$ ATAKA zarejestrowała się jako partia 12.07.2005 r., zob. Софийски градски съд, Официална уеб страница на СГС, https://sgs.justice.bg/bg/14755, (dostęp: 07.06.2020).

${ }^{29}$ Програмна схема, Официален уебсайт на ПП АТАКА, https://web.archive.org/web/20070622175612/ http://www.ataka.bg/index.php?option=com_content\&task=view\&id=14\&Itemid=29, (dostęp: 07.06.2020).

${ }^{30}$ R. Brubaker, Nacjonalizm inaczej..., s. 131-132. 
1. Bułgaria jest jednonarodowym, zjednoczonym państwem, niepodlegającym podziałowi w żadnym z poniższych wskazań: wyznaniowym, etnicznym, kulturowym. Różnice w pochodzeniu lub religii nie mogą stać ponad narodową przynależnością. Kto tak czyni, sam oddala się od bułgarskiej nacji i państwa, i nie może wysuwać wobec nich żadnych roszczeń ${ }^{31}$.

2. Oficjalnym językiem w Bułgarii jest bułgarski, a w publicznych mediach utrzymywanych z państwowego budżetu nie można prowadzić emisji w innym języku. Zakaz i jasne sankcje wobec partii etnicznych i organizacji separatystycznych ${ }^{32}$.

Drugi postulat stanowił kluczowe dążenie ugrupowania, które po wyborach $2009 \mathrm{r}$. nieformalnie wspierało mniejszościowy rząd Bojko Borisowa. 15 grudnia 2009 r. odbyła się wspólna konferencja prasowa premiera i Wolena Siderowa dotycząca organizacji referendum narodowego, które miało zadecydować o nadawaniu wiadomości w języku tureckim. ATAKA oczekiwała, że społeczeństwo wypowie się przeciwko tureckojęzycznej emisji w telewizji publicznej ${ }^{33}$. Chociaż Borisow początkowo popierał sam pomysł, po kilku dniach - pod wpływem presji prezydenta, opozycji oraz instytucji UE, anulował swoją aprobatę $e^{34}$.

Jednak wydarzeniem, który ostatecznie ukształtowało negatywny wizerunek partii, był atak na sofijski meczet Banja Basza (bułg. Баня Башъ) w maju 2011 r. Około setki działaczy ATAKA zebrało się pod świątynią w porze piątkowej modlitwy, aby zakłócić jej przebieg. Powodem protestu było hałas dochodzący ze świątyni, który miał przeszkadzać mieszkańcom. Protest i agresja słowna przerodziły się w bójkę z wiernymi. Kilkadziesiąt osób zostało rannych. Wolen Siderow przekonywał, że to muzułmanie napadli protestujący tłum. Wynikiem tego skandalicznego incydentu była sprawa przed Europejskim Trybunałem Praw Człowieka w Strasburgu - Karaahmed przeciwko Bułgarii ${ }^{35}$. Jeden z poszkodowanych złożył skargę do trybunału, który orzekł na niekorzyść państwa i nakazał wypłatę odszkodowania. W uzasadnieniu wyroku przekonywano, że państwo nie zagwarantowało obywatelom bezpieczeństwa w kontekście wolności wyznania. Formalnie bułgarski wymiar sprawiedliwości do dnia dzisiejszego nie skazał osób odpowiedzialnych za ten atak. Jakkolwiek reakcja opinii publicznej w sposób jednoznaczny pokazała sprzeciw wobec podobnych aktów agresji religijnej, ATAKA nie poniosła konsekwencji prawnych swojego działania.

\footnotetext{
${ }^{31} \mathrm{~W}$ oryginale : 1. България е еднонационална, монолитна държава, неподлежаща на разделяне по нито един от следните принципи: верски, етнически, културен. Различието по произход или вяра не може да се поставя над националната принадлежност. Който прави това, се самоотделя от българската нация и държава и не може да има никакви претенции към тях, [za:] 20 точки на партия АТАКА, Офицйален уебсайт на ПП АТАКА, https://web.archive.org/web/20110508120244/http://www.ataka.bg/index. php?option=com_content\&task=view\&id=13\&Itemid=34, (dostęp: 07.06.2020).

${ }^{32} \mathrm{~W}$ oryginale: 2. Официалният език в България е българският и в националните медии, издържани от държавния бюджет, не може да има емисии на друг език. Забрана и ясни санкиии за етнически партии и сепаратистки организаичи, [za:] Ibidem, (dostęp: 07.06.2020).

${ }^{33}$ Emisja trwa krócej niż kwadrans dziennie - przyp. autorki.

34 Борисов коментира промяната на решението си за рефендум за новините на турски по БНТ, Портал БНТ, 20.12.2009, https://news.bnt.bg/bg/a/19945-borisov_komentira_promjanata_na_reshenieto_si_za_ refendum_za_novinite_na_turski_po_bnt, (dostęp: 07.06.2020).

${ }_{35} \mathrm{Więcej} \mathrm{na} \mathrm{temat} \mathrm{wydarzeń} \mathrm{z} 20.05 .2011 \mathrm{r}$. oraz samego procesu zob. ECHR, Karaahmed vs. Bulgaria, App. 30587/13, http://hudoc.echr.coe.int/eng?i=001-152382, (dostęp: 08.06.2020).
} 
Wewnętrzna Macedońska Organizacji Rewolucyjna - Bułgarski Ruch Narodowy została założona w $1999 \mathrm{r}^{36}$, ale jako organizacja społeczno-kulturowa działała od $1989 \mathrm{r}^{37}$ Jej politycy uczestniczyli wówczas w wyborach, przyłączając się regularnie do większych bloków koalicyjnych, np. ODS ${ }^{38}$. W ramach zaproponowanego programu WMRO-BND w znacznym stopniu scalała się z propozycjami ATAKI. Wart jednak wyróżnienia jest punkt dotyczący polityki zagranicznej, emblematyczny dla działalności partii:

[...] 2. Wejście Turcji do Unii Europejskiej jest również poważnym zagrożeniem dla istnienia Bułgarii. [...] Dzisiaj jesteśmy świadkami wchodzenia tureckiego kapitału i wpływu kulturowego. Ponadto interesów politycznych, przedstawianych przez niekonstytucyjną turecką etniczną i religijną partię, DPS. Dzisiaj państwo tureckie pozwala sobie na niedopuszczalną ingerencję w sprawy wewnątrzpaństwowe Republiki Bułgarii. Bez granicy, zwanej Unią Europejską, te zjawiska wymkną się spod kontroli ${ }^{39}$.

Ze względów historycznych, jak też geopolitycznych, Republika Turcji jest uważana za największe zagrożenie dla bezpieczeństwa narodowego Bułgarii. Dyskredytowanie oraz ukazywanie południowego sąsiada jako kraju antydemokratycznego i ekspansywnego jest kluczowym celem partii. Turcja musi pozostawać poza zewnętrznymi granicami UE, aby nie naruszać stabilności regionu Półwyspu Bałkańskiego. WMRO prowadzi aktywną antyturecką agitację w internecie. Na oficjalnej stronie partii istnieje specjalny dział zatytułowany „Turcja zdemaskowana” (bułg. Турция разбулена), gdzie można odnaleźć wiele publikacji poświęconych sprawom tureckim. Ich nagłówki jednoznacznie określają ton stosowanej retoryki: O neoosmanizmie, Bułgarii i tureckich producentach w naszym kraju (bułg. За неоосманизма, България и турските мекерета у нас ${ }^{40}$ ), Czy Erdogan przygotowuje tureckq ekspansję? (bułg. Подготвя ли Ердоган турската експанзия? ${ }^{41}$ ), Dokqd będziemy znosić przeinaczanie bułgarskiej historii? (bułg. До кога ще търпим гавра с българската история? ${ }^{42}$ ), etc. Ostatni z przykładów ukazuje również kategoryczne stanowisko WMRO-BND wobec interpretowania bułgarskich dziejów. W grudniu 2015 r. telewizja Al Jazeera wyemitowała film dokumentalny pt. „Bułgaria, moja ojczyzna”,

\footnotetext{
${ }^{36} \mathrm{CГC}$, Регистър на политическите партии, https://sgs.justice.bg/bg/14755, (dostęp: 20.06.2020).

${ }^{37}$ Wówczas jako WMRO- SMD (bułg. ВMPO-СМД, ВМРО-Съюз на македонските дружества) - przyp. autorki.

${ }^{38}$ ODS - Zjednoczenie Sił Demokratycznych, bułg. Обединение на демократичните сили, ОДС.

${ }^{39} \mathrm{~W}$ oryginale: [...] 2. Влизането на Туриия в ЕС е също сериозна заплаха за съществуването на България.[...] Днес сме свидетели на навлизането на турски капитали и културно влияние. А и на политически интереси, представяни от противоконституционната турска етническа и религиозна партия ДПС. И днес турската държсава си позволява да се намесва недопустимо във вътрешните работи на Република България. Без гранииата, наречена ЕС, тези процеси ще станат неконтролируеми, [za:] Програма на ВМРО-БНД, Официален уебсайт на ВМРО-БНД, www.vmro.bg/pages/документи/програма/, (dostęp: 13.05.2020).

${ }^{40}$ А. Джамбазки, За неоосманизма, България и турските мекерета у нас, 15.12.2013, Официален уебсайт на ВМРО-БНД, http://www.vmro.bg/za-neoosmanizma-blgariia-i-turskite-mekereta-u-nas/, (dostęp: 21.06.2020).

${ }^{41}$ В. Митов, Подготвя ли Ердоган турската експанзия?, 31.03.2019, ibidem, http://www.vmro.bg/ category/turtsiia-razbulena/?page=1, (dostęp: 21.06.2020).

${ }^{42}$ К. Каракачанов, Докога ще търпим гавра с българската история, ibidem, 22.12.2015, https://tinyurl. com/yd8rwytz, (dostęp: 13.05.2020).

${ }^{43}$ Y. Yanat Bagci, Bulgaria, my land, Al Jazeera, https://www.aljazeera.com/programmes/aljazeeraworld/2015/12/bulgaria-land-151215080838910.html, (dostęp: 14.05.2020).
} 
opowiadający o losach mniejszości tureckiej w czasach komunizmu. Przedstawiano represje za czasów BRL oraz bieżące problemy. Karakaczanow odniósł się do dokumentu i skrytykował władze bułgarskie za zbyt pobłażliwą politykę etniczną:

[...] Bułgaria jest jednym z przykładów tolerancyjnego stosunku wobec różnych etnosów. W tym momencie - nawet zbyt tolerancyjnego. [...] Zamachy w Paryżu pokazały, że naiwna tolerancja jest samobójstwem. Bułgaria robi wystarczająco dużo, aby gwarantować prawa swoim obywatelom różnego pochodzenia i wyznania. Dlatego bezpodstawne są wszelkie próby rzucające cień na nasz kraj. Infantylna liberalizacja pokazuje swoją niestabilnośćc4.

„Katastrofa demograficzna”, do której odwołuje się w swojej deklaracji WMRO-BND, to nie tylko typowe wyzwania kraju, który boryka się z niskim przyrostem naturalnym czy masową emigracją zarobkową. $\mathrm{W}$ odczuciu ugrupowania jest nim również mapa etniczna Bułgarii, a co z tym związane - rosnący wpływ mniejszości na kształt całego społeczeństwa. W państwie bułgarskim, gdzie wspólnota polityczna koresponduje ze sferą etniczności i wyznania, ingerencja innych etnosów i religii mniejszościowych jest postrzegana jako zamach na tożsamość i tradycyjne wartości ${ }^{45}$.

Podobnie jak ATAKA, WMRO-BND podważa legalność partii Ruch na rzecz Praw i Swobód. Poza argumentem o niekonstytucyjności tej formacji politycznej, podnoszony jest zarzut o bezprawnym realizowaniu tureckich interesów za pośrednictwem deputowanych DPS. Działacze WMRO-BND wprost nazywają to ingerencją obcego państwa w sprawy wewnętrzne Bułgarii. Z czasem wrogi stosunek WMRO-BND rozszerzył się także na nowe ugrupowania skupiające bułgarskich Turków jak NPSD ${ }^{46}$ oraz DOST $^{47}{ }^{48}$. Zdrada interesów narodowych stanowi w rozumieniu dwóch nacjonalistycznych partii przestępstwo, które powinno być ścigane na mocy kodeksu karnego.

Trzeci z koalicjantów, Narodowy Front Ocalenia Bułgarii, jest formacją polityczną o najkrótszym stażu, powstał bowiem 17 maja 2011 r. w Warnie ${ }^{49}$. Jego przewodniczącym jest Waleri Simeonow, który dotychczas był kojarzony jako właściciel prywatnej telewizji SKAT (bułg. CKAT). To właśnie w niej zdobywał rozgłos Wolen Siderow w cyklicznej audycji „Ataka”. Simeonow, który otwarcie popierał polityka, sprawował funkcję prze-

${ }^{44} \mathrm{~W}$ oryginale : [...] България е един от примерите за толерантно отночение към различни етноси. На моменти - даже прекалено толерантно. [...] Атентатите в Париж показаха, че наивната толерантност е самоубийство. България вече прави достатъчно, за да гарантира правата на свочте граждани от различен произход и религиозна общност. Затова и са безпочвени всякакви назидания, хвърлящи тъмна сянка върху страната ни. Инфантилната либералщина очевидно доказа несъстоятелността си, [za:] К. Каракачанов, Докога щее търпим..., Официален уебсайт на ВМРО-БНД, 22.12.2015, https://tinyurl.com/yd8rwytz (dostęp: 13.05.2020).

${ }^{45}$ J. Jackson Preece, Prawa mniejszości, Warszawa 2007, s. 49.

${ }^{46}$ NPSD - Ludowa Partia „Wolność i Godność”, bułg. Народна партия „Свобода и достойнство”, НПСД.

${ }^{47}$ DOST - Demokraci dla Odpowiedzialności, Wolności i Tolerancji, Демократи за отговорност, свобода и толерантност, ДОСТ.

${ }^{48}$ МВМРО-БНД, ДПС и ДОСТ работят против българския интерес, 02.04.2020, ibidem, https://tinyurl. com/y9y3fsnh, (dostęp: 21.06.2020); А. Джамбазки, БСП позорно трбва да мълчи, защяото те са съучастници на Туричя, ДОСТ да бъдат разследвани за наџчионално предателство, 02.04.2019, ibidem, https://tinyurl. com/ybculmww, (dostęp: 21.06.2020).

49 Устав на НФСБ, Официален уебсайт на НФСБ, http://www.nfsb.bg/public/documents/ustav_2017 edition.pdf, (dostęp: 21.06.2020). 
wodniczącego partii w regionie burgaskim. Dopiero kilka lat później zdecydował się stworzyć autonomiczne stronnictwo. Priorytetem NFSB jest zdrowa, bogata i silna nacja, która przywróci Bułgarii należną pozycję na Bałkanach oraz w Unii Europejskiej ${ }^{50}$. Aby umocnić naród, partia poszukuje rozwiązań w restrykcyjnej polityce etnicznej, co potwierdza poniższy punkt programu:

[...] 5. Zakaz jakichkolwiek partii opartych na normach etnicznych i religijnych. Zakaz wszystkich przywilejów ze względów etnicznych i religijnych ${ }^{51}$.

Pierwsza zdanie jest tożsame z art. 11.4. bułgarskiej konstytucji. Natomiast kolejne zawiera propozycję, aby państwo odrzuciło wszelkie prawa i wolności zapisane w ustawie zasadniczej, które w jakikolwiek sposób wyróżniają grupy etniczne i religijne. Trudno jednakże logicznie interpretować ten postulat, ponieważ sformułowanie zakaz wszystkich przywilejów ze względów etnicznych i religijnych można by zaadresować do narodu bułgarskiego i religii prawosławnej, które według tego samego dokumentu powinny uzyskać status specjalny (zob. punkty $3,4,5)^{52}$. Jako istotne narzędzie kształtowania świadomości narodowej wymieniany jest także język:

[...] 16. Zmiany w Kodeksie wyborczym, aby prawo głosu posiadali tylko obywatele, którzy mogą potwierdzić dobrą znajomość języka bułgarskiego w mowie i piśmie ${ }^{53}$.

Punkt 16. wyjaśnia zamiar partii, aby czynne prawo wyborcze opierać na cenzusie językowym, co uderza w mniejszości - zwłaszcza turecką i romską. W skomasowanych regionach na południu kraju przeważa ludność, dla której pomimo obowiązku nauki bułgarskiego, stanowi on język drugiego wyboru. Celem NFSB jest w rzeczywistości ograniczenie prawa głosu. Warto nadmienić, że kodeks wyborczy Republiki Bułgarii stosuje już pewne restrykcje w zakresie używania języka mniejszości, gdyż agitację polityczną można sprawować tylko po bułgarsku.

Wrogi stosunek partii OP wobec organizacji politycznych kojarzonych ze środowiskiem bułgarskich Turków nasilił się w trakcie kampanii przed wyborami parlamentarnymi w 2017 r. W reakcji na klip promujący koalicję „Zjednoczenie DOST” (bułg. Обединение ДОСТ), Patrioci złożyli zażalenie do Centralnej Komisji Wyborczej. Przyczyną było fragmentaryczne użycie w nim jezzyka tureckiego, co stało w sprzeczności z przepisami kodeksu wyborczego. Ponadto spot odwoływał się do historycznego wspomnienia tzw. „procesu odrodzeniowego" i wydarzeń z maja $1989 \mathrm{r}^{54}$, co nie podobało się nacjonalistom, którzy

${ }^{50} \mathrm{~W}$ oryginale: 1. Здрава, богата и силна нация - основа за въздигането, просперирането на България и нейното превръщане в основен фактор, както на Балканите, така и в ЕС, [w:] НФСБ, Основни иели на Национален Фронт за Спасение България, http://www.nfsb.bg/targets.php, (dostęp: 13.05.2020).

${ }^{51} \mathrm{~W}$ oryginale: 5. Забрана на всякакви партии основани на етнически и религиозен принцип. Забрана на всички привилеги по етнически и религиозен принции, [za:] НФСБ, Основни цели на Национален Фронт за Спасение България, http://www.nfsb.bg/targets.php, ibidem, (dostęp: 13.05.2020).

${ }^{52}$ Ibidem, (dostęp: 13.05.2020).

${ }^{53} \mathrm{~W}$ oryginale: 16. Промени в избирателния закон, като право на глас могат да имат граждани, доказали добро владеене на писмен и говорим български език, [za:] ibidem, (dostęp: 13.05.2020).

${ }^{54}$ Tzw. ,proces odrodzeniowy” był okresem represji wobec bułgarskich muzułmanów mieszkających w BRL. Ludność turecką dotknął w sposób szczególny w latach 1984-1985, jednak pierwsze działania ograniczające prawa i wolności muzułmanów rozpoczęły się jeszcze w połowie lat 50 . Władze ingerowały w życie osobiste jednostek, w tym np. zmianę imienia i nazwiska na bułgarsko brzmiące. W maju 1989 r. doszło do masowej 
deprecjonują represje tamtego okresu. W odpowiedzi na zakaz emisji, Zjednoczenie opublikowało ten sam film w popularnym serwisie youtube.com, tym razem jednak wyłącznie w wersji tureckojęzycznej ${ }^{55}$. Kolejnym krokiem nacjonalistów było zorganizowanie blokady przejścia granicznego z Turcją zaledwie kilka dni przed planowanymi wyborami. Tak dziennik „Ataka” (bułg. вестник „АТАКА”) relacjonował słowa Wolena Siderowa, który kierował tym przedsięwzięciem:

[...] Autobusy z wyborcami przybywają do kraju, głosować, decydować o losie Bułgarów..., to są ludzie, którzy ani nie płacą podatków w Bułgarii, ani nie mają już nic wspólnego z Bułgarią. To nie jest normalne, trzeba to zatrzymać, bo inaczej Ankara dalej będzie wspierać antybułgarskie partie tureckiego wywiadu ${ }^{56}$.

Po wyborach 26 marca 2017 r. nacjonaliści wspólnie z partią GERB sięgnęli po władzę wykonawczą. Jakkolwiek poprzednie dwa programy rządu Borisowa nie skupiały szczególnej uwagi na sprawach mniejszości, nowa agenda na lata 2017-2021 jeszcze skromniej odnosiła się do kwestii polityki etnicznej. Było wiadome, że wpływ na jej kształt mieli również partnerzy koalicyjni. Dowodem tej zmiany jest program z 2014 r., w którym funkcjonował zapis o wspólnym dziedzictwie etnokulturowym Bułgarii, wpisującym się jako część kultury narodowej:

[...] Promowanie tworzenia nowego środowiska duchowego dla etnokulturalnych wpływów $i$ integracji wszystkich religijnych grup w zjednoczonym narodzie bułgarskim ${ }^{57}$.

Wprawdzie był to priorytet o charakterze deklaratywnym, lecz przynajmniej uznawał grupy etniczne jako podmiot rodzimego kręgu kultury. Strategia z roku 2017 nie zawierała podobnych sugestii. Wiele miejsca poświęcała natomiast promocji kultury i języka bułgarskiego w kraju i za granicą.

Dotychczas prężnie rozwijany dział polityki antydyskryminacyjnej w dokumencie odnosił się jedynie do kwestii równouprawnienia płci. Etniczna równość obywateli Bułgarii została pominięta, chociaż jednym z pryncypiów, które przyświecały nowemu rządowi, była Tolerancja, przeciwdziałanie dyskryminacji i dezintegracji (bułg. Толерантност,

emigracji muzułmanów do sąsiedniej Republiki Turcji. W ciągu niecałych trzech miesięcy emigrowało ok. 350400 tys. obywateli - przyp. autorki. Więcej na temat przymusowej asymilacji muzułmanów w BRL - zob. М. Груев, Възродителният проиес, София 2008; А. Eminov, There are no Turks in Bulgaria, [w:] „International Journal of Turkish Studies", 4, 1990.

${ }^{55}$ П. Найденова, Обединени патриоти - НФСБ, АТАКА и ВМРО сезираха ЦИК за нов скандален клип на ДОСТ, в. „Ataka”, 20.03.2017, https://tinyurl.com/y7u3pf3d, (dostęp: 18.05.2020).

${ }^{56} \mathrm{~W}$ oryginale: [...] автобусите с избиратели идват в страната, гласуват, решават съдбата на българите...това са хора, които нито плащат данъци в България, нито имат нещо общо вече с България. „Това не е нормално, трябва да спре, защото по този начин се поддържат от Анкара антибългарски партии, на турските спеислужби", [zа:] П. Найденова, Обединени патриоти- НФСБ, АТАКА и ВМРО блокираха границата с Туриия!, в. „Атака”, 21.03.2017, https://tinyurl.com/yd9clqkr, (dostęp: 22.06.2020).

${ }^{57} \mathrm{~W}$ oryginale: [...] НАСЪРЧАВАНЕ ФОРМИРАНЕТО НА НОВА ДУХОВНА СРЕДА ЗА ЕТНОКУЛТУРНО ВЗАИМОДЕЙСТВИЕ И ИНТЕГРАЦИЯ НА ВСИЧКИ РЕЛИГИОЗНИ ГРУПИ В ЕДИННАТА БЪЛГАРСКА НАЦИЯ, [za:] Приоритет 17.1., Култура и духовност, [w:] Програма на правителството за стабилно развитие на Република България за периода 2014-2018 2., Sofia 2014, http://www.strategy.bg/ StrategicDocuments/View.aspx?lang=bg-BG\&Id=950, s. 130, (dostęp: 12.05.2020). 
недопускане на дискриминация и дезинтеграция) ${ }^{58}$. Tymczasem w 2017 r. Europejski Trybunał Praw Człowieka zajmował się 582 sprawami, a rok później - 774, których wnioskodawcami byli obywatele Bułgarii ${ }^{59}$. Część z nich dotyczyła wolności sumienia, zgromadzeń, prawa do edukacji czy zapewnienia bezpieczeństwa, mając bezpośredni związek z brakami w realizacji praw mniejszości. Ponadto Republika Bułgarii odznacza się opieszałością w kwestii implementacji wyroków trybunału. W 2018 r. 208 orzeczeń wciąż oczekiwało wykonania ${ }^{60}$. W agendzie rządowej postulaty rozwijające zadania polityki etnicznej państwa pojawiają się enigmatycznie i są łączone z rozwiązaniami konkretnych regulacji sektorowych, np. w oświacie lub polityce społecznej:

[...] Zapewnienie warunków nauczania włączającego dzieci i uczniów z mniejszości etnicznych poprzez dodatkowe moduły dla tych, które nie władająjęzykiem bułgarskim w przedszkolach $^{61}$.

Warto zwrócić uwagę, że powyższy zapis nie umożliwia edukacji w języku mniejszości, która wynika ze zobowiązań zawartych w Konwencji ramowej o ochronie mniejszości narodowych ${ }^{62}$. Normuje natomiast obowiązkową naukę języka bułgarskiego, co jest zapisane w konstytucji (art. 36 $6^{63}$ ). Celem tego działania jest integracja w ramach jednolitej wspólnoty językowej. Brakuje zapisów, które wspierałyby i zachęcały do nauki języków mniejszościowych. Kolejny punkt odwołuje się do polityki socjalnej:

[...] Rozszerzenie świadczeń usług rehabilitacyjnych/ terapeutycznych z naciskiem na usługi, które skupiają się na zapewnianiu ciągłej opieki dla osób fizycznych, uwzględnieniu społecznej (re-)integracji, potrzeb związanych z płcią i dotarciem do społeczności wrażliwych, w tym dzieci i młodzieży, mniejszości etnicznych, migrantów i osób ubiegających się o azyl, więźniów, osób żyjących z HIV/ AIDS oraz bezdomnych ${ }^{64}$.

Odnosi się to do celu nr 117, który strategicznie obejmuje walkę z narkomanią. Wśród grup ryzyka wyeksponowanych w sposób szczególny na ten problem społeczny autorzy

\footnotetext{
${ }^{58}$ Министерски съвет на Република България, Програма за управление на правителството на Република България за периода 2017-2021 г., https://www.government.bg/files/common/GovPr_2017-2021.pdf, (dostęp: 17.05.2020).

${ }^{59}$ ECHR, Annual report 2018, Strasburg 2018, s. 174, https://www.echr.coe.int/Documents/Annual_report_ 2018 ENG.pdf, (dostęp: 22.06.2020).

${ }^{60}$ Committee of Ministers of Council of Europe, 13th Annual report of the Committee of Ministers. Supervision of the Execution of judgments and decisions of the European Court of Human Rights, Strasburg 2019, s. 60, https://rm.coe.int/annual-report-2019/16809ec315, (dostęp: 22.06.2020).

${ }^{61} \mathrm{~W}$ oryginale: [...] Осигуряване на условия за приобщзаващзо образование на децата и учениците от етническите малцинства чрез допълнителни модули за деца, които не владеят български език в детските градини, [w:] Цел 95, ibidem, s. 46.

${ }^{62}$ Bułgaria ratyfikowała ten dokument w 1999 r. - przyp. autorki.

${ }^{63}$ Art. 36: (1) Nauka języka bułgarskiego i postugiwanie się nim stanowia prawo i obowiazek obywateli butgarskich, [za:] Konstytucja Republiki Butgarii 1991, Warszawa 2012, s. 64, http://libr.sejm.gov.pl/tek01/txt/ konst/bulgaria2013.pdf, (dostęp: 22.06.2020).

${ }^{64} \mathrm{~W}$ oryginale: [...] Разииряване на предлагането на услуги за рехабилитация/възстановяване с акиент върху услугите, които са съсредоточени върху предоставянето на непрекъснати грижи за лицата, подпомагат социалната (ре)интеграция, вземат предвид специфичните свързани с пола нужди и достигат до уязвимите общности, включително децата и подрастващите, етническите малцинства, мигрантите и тьрсещите убежище, затворниците, хората, живеещи с ХИВ/СПИН, и бездомните, [za:] Цел 117, ibidem, s. 55.
} 
wymienili mniejszości etniczne. Cel nr 142 kieruje działanie władz na promocję instytucji kultury, takich jak scena teatralna, muzyczna czy taneczna:

[...] Poprawa dostępu obywateli znajdujących się w niekorzystnej sytuacji oraz etnicznych i mniejszościowych społeczności do produktów teatralnych, muzycznych i tanecznych ${ }^{65}$.

Nie jest to jednak rozwiązanie, które będzie promować rozwój i ochronę kultur mniejszościowych. Zapis dotyczy wyłącznie kultury bułgarskiej.

Podsumowując program rządu na lata 2017-2021, należy przyznać, że nie pomijał on całkowicie zagadnień związanych z grupami etnicznymi. Niemniej każde z obecnych tam odniesień implementowało mechanizm integracyjny (włączający). Nowo wybrany rząd zrezygnował z budowania społeczeństwa opartego na różnorodności. Kluczowe jest wspieranie większościowego kręgu kultury, a bogactwem i siłą Bułgarii jest zjednoczenie wokół tego, co rdzennie bułgarskie. Mniejszości etniczne mogą legalnie pielęgnować swój dorobek kulturowy, jednak bez wyraźnego patronatu ze strony instytucji państwowych. Porównując rozwiązania, które proponowały poprzednie gabinety po 2000 r., zauważalną tendencjąjest stopniowe odsuwanie się państwa od założeń tzw. bułgarskiego modelu etnicznego, który jeszcze w czasach rządu Sergieja Staniszewa był określany jako rodzimy produkt eksportowy ${ }^{66}$.

Po utworzeniu gabinetu zapadła decyzja, aby wicepremiera i ministra ds. gospodarczych i demograficznych, Waleriego Simeonowa, mianować na przewodniczącego Narodowej Rady Współpracy ds. etnicznych i integracyjnych (bułg. Национален съвет по сътрудничество по етническите и интеграционните въпроси, НССЕИВ, pl. NSSEIW) ${ }^{67}$. Było to posunięcie, które doprowadziło do odejścia większości organizacji pozarządowych, dotychczas współpracujących z tym organem ${ }^{68}$. Bojkot ogłosiły zwłaszcza stowarzyszenia romskie, ponieważ w 2014 r. Simeonow, wówczas jeszcze deputowany z ramienia Frontu Patriotycznego, nazwał Romów z mównicy parlamentarnej zuchwałymi, aroganckimi i okrutnymi człekokształtnymi, a w kontekście romskich matek, które pobierają środki pomocy społecznej, użył wyrażenia - kobiety z instynktem ulicznych suk ${ }^{69}$. Mimo że tamta wypowiedź stała się przedmiotem postępowania sądowego, ostatecznie 15 stycznia 2019 r. Naczelny Sąd Administracyjny uniewinnił Simeonowa, uzasadniając, że opinia padła w odniesieniu do niesprecyzowanej grupy osób, stąd nie narusza godności konkret-

\footnotetext{
${ }^{65} \mathrm{~W}$ oryginale: [...] Подобряване достъпа на гражданите в неравностойно положение и на етническите и малцинствените общчнсти до театралните, музикалните и танцови продукти, [zа:] Цел 142, ibidem, s. 65 .

${ }^{66}$ Програма на правителство на европейска интеграция, икономическия растеж и сочиялната отговорност 2005-2009, http://old.europe.bg/upload/docs/GovernmentalProgramme_final_bg.pdf, s. 7, (dostęp: 22.06.2020).

${ }^{67}$ Решение но 290 от 25 май 2017 г., http://pris.government.bg/prin/document_view.aspx?DocumentID= UJNEAox1U14dqwGAi3XoOw==, (dostęp: 22.06.2020).

${ }^{68}$ Български хелзински комитет, Правата на човека в България през 2017, http://www.bghelsinki.org/ media/uploads/doklad2018.pdf, (dostęp: 22.06.2020), s. 13-14.

${ }^{69} \mathrm{~W}$ oryginale: Защу хора [...] сега са се превърнали в нагли, самонадеяни и озверели човекоподобни, изискващи право на заплати без да полагат труд, изискващчи помощчи по болест без да са болни, детски за деца, които играят с прасетата на улицата, и майчински помощи за жени с инстинкти на улични кучки?, [za:] Стенограми от пленарни заседания на 43-то Народно събрание, 17.12.2014, https://www. parliament.bg/bg/plenaryst/ns/51/ID/5328, (dostęp: 22.06.2020).
} 
nych przedstawicieli społeczności romskiej. Dodano również, że interwencja Komisji ds. przeciwdziałania dyskryminacji (bułg. Комисия за защита срешу дискриминация, КЗД, pl. KZD) była w tym wypadku bezpodstawna, gdyż wypowiadanie prywatnych opinii mieści się $\mathrm{w}$ granicach wolności wypowiedzi ${ }^{70}$. Był to kolejny z przykładów, kiedy propagowanie aktów i mowy nienawiści, penalizowane od 2015 r. na podstawie kodeksu karnego, pozostało osądzone bez konsekwencji. Ostatecznie kadencja Simeonowa jako przewodniczącego NSSEIW nie trwała długo, gdyż jesienią 2018 r. po kolejnej kontrowersyjnej wypowiedzi (tym razem skierowanej wobec rodziców dzieci niepełnosprawnych), polityk został zmuszony, aby złożyć dymisję ze wszystkich funkcji ${ }^{71}$.

Często z parlamentarnej trybuny padają słowa krytyki Patriotów wobec sąsiedniej Turcji. Podczas debaty nad stanem bezpieczeństwa narodowego, Paweł Szopow (bułg. Павел Шопов) z partii ATAKA ostrzegał, że Turcja od 140 lat stanowi zagrożenie dla bezpieczeństwa Bułgarii:

[...] Nie rozumiem czemu służy to zalecanie się do Turcji i co zyskujemy, aby zwróciły nam się te spotkania i umowa z sąsiednim krajem, dużym i silnym gospodarczo, który ma swoje wielkoimperialne dążenia i cele, który zaszczepia swoją politykę w Bułgarii poprzez pewną turecką, nacjonalistyczną partię w postaci DPS. A my to wszystko winniśmy przemilczeć, tylko dlatego, że Turcja jest członkiem NATO ${ }^{72}$

Polityka zagraniczna, którą proponują ugrupowania tworzące OP, powinna skupiać się wokół osłabiania regionalnego potencjału Turcji gospodarczo lub politycznie - szczególnie w perspektywie jej możliwego członkostwa w Unii Europejskiej. Zwłaszcza prezydentura Recepa T. Erdoğana jest postrzegana przez Patriotów jako czynnik wysokiego ryzyka dla Bułgarii, ale także całej Europy, o czym przekonywał w poniższej wypowiedzi czołowy polityk WMRO-BND, Angeł Dżambaski (bułg. Ангел Джамбаски):

[...] Już od ponad pięciu lat mówimy o tym, ostrzegamy. Ten człowiek (Erdoğan - przyp. autora) jest dyktatorem, nie obchodzą go prawa człowieka. Napada Kurdów w Syrii, tak samo jak Cypr, zastrasza Grecję i Bułgarię [...] stąd pytanie, co robi UE na naszych oczach. Należy zatrzymać całe finansowe wsparcie UE dla Turcji ${ }^{73}$.

${ }^{70}$ BAC, Решение но 636 от 15.01.2019, http://www.sac.government.bg/court22.nsf/d6397429a 99ee2afc225661e00383a86/211a54167a5a1cb5c225837e0034a472?OpenDocument, (dostęp: 22.06.2020).

${ }^{71}$ Валери Симеонов подаде оставка, за да не тежи „, като воденичен камък на правителството”, 16.11.2018, портал Mediapool, https://www.mediapool.bg/valeri-simeonov-podade-ostavka-za-da-ne-tezhi-katovodenichen-kamak-na-pravitelstvoto-news286388.html, (dostęp: 22.06.2020).

${ }^{72} \mathrm{~W}$ oryginale: Не мога да разбера за какво са тези флиртове с Туриия и какво печелим, за да се въртят тези срещи и този дослук с една съседна държава, голяма и силна икономически, която има свочте великоимперски стремежи и цели. Която насажда своята политика в България чрез една турска националистическа партия в лицето на ДПС и ние всичко това да го премълчаваме само защото Туриия е в НАТО ли, [za:] П. Дучев, Шопов от АТАКА: 140 години Турчия е заплаха за България, в. „Атака”, 16.03.2018, https://tinyurl.com/y7e2zrfd, (dostęp: 22.06.2020).

${ }^{73} \mathrm{~W}$ oryginale: Говорим, предупреждаваме за това вече 5 години. Този човек (Ердоган - б.р.) е диктатор, не се интересува от човешки права. Напада както кюрдите в Сирия, така и Кипьр, застрашава Гъриия и България. [...]Въпросът е какво прави ЕС във ваше лице. Трябва да бъда спрени всички финансови потоци на ЕС към Туричи, [za:] А. Джамбазки, Ердоган е агресор и окупатор. Фолксваген трябва да се откаже от Турциия, Новитите.бг, 10.10.2019, https://tinyurl.com/y9azcmj6, (dostęp: 22.06.2020). 
Kolejnym motywem ideologicznym, wciąż aktualnym w retoryce partii ATAKA, jest spór o odszkodowanie, którego atakiści żądają za grabież trakijskich majątków należących do Bułgarów do roku 1913. Ugrupowanie ocenia rekompensatę na 10 mld dolarów, jednakże ten postulat - tak szeroko komentowany przez partię w mediach - nigdy nie wyszedł poza ramy politycznej debaty. Wolen Siderow obarcza za tę dyplomatyczną porażkę premiera Borisowa, który przedkłada bezkonfliktowe relacje z południowym sąsiadem nad dobro własnego narodu ${ }^{74}$.

Znamiennym symbolem wzrastającego wpływu środowisk nacjonalistycznych w Bułgarii jest tzw. marsz Łukowa (bułg. Луковмарш). Jest to coroczne wydarzenie organizowane przez działaczy związanych z Bułgarskim Związkiem Narodowym (bułg. Български народен съюз, БНС, pl. BNS). Biorą w nim udział europejskie organizacje skrajnej prawicy oraz neonazistowskie. Celem przedsięwzięcia jest upamiętnienie osoby gen. Christo Łukowa (bułg. Христо Луков), którego życiorys budzi kontrowersje, gdyż kolaborował on z III Rzeszą. Inicjatywa pochodu wielokrotnie skupiała uwagę organizacji międzynarodowych, w tym Komisji Praw Człowieka ONZ ${ }^{75}$. Z drugiej strony w obronie przemarszu stają najważniejsi politycy koalicji rządzącej. W 2012 r. Dżambaski powiedział, że łączenie osoby gen. Łukowa $\mathrm{z}$ nazizmem jest błędem i stoja za tym ludzie z problemami hormonalnymi, którzy nie czytaja i nie znaja historii ${ }^{76}$. W 2020 r. burmistrz Sofii, Jordanka Fandykowa (bułg. Йорданка Фандъкова) zakazała organizacji marszu. Potwierdził to swoją decyzją także Naczelny Sąd Administracyjny ${ }^{77}$. Pomimo orzeczenia, około stu osób zebrało się na obchodach, choć nie były one tak liczne jak co roku.

Koalicja Zjednoczonych Patriotów przetrwała w oryginalnym składzie jedynie trzy lata. Wskutek nieporozumień wewnętrznych w lipcu 2019 r. WMRO-BND i NFSB zdecydowały się rozdzielić sojusz z partią Wolena Siderowa ${ }^{78}$. Decyzja o wyłączeniu trzech deputowanych ATAKI z grupy parlamentarnej OP (w tym samego lidera partii) została przypieczętowana tuż przed wyborami do Parlamentu Europejskiego. Nie tylko ambicje Siderowa, ale również postępujące oddalenie ideologiczne, miały stać się przyczyną rozłamu. Pomimo zmian, koalicja rządząca GERB-OP nie przestała istnieć, a Krasimir Karakaczanow wciąż pełni rolę ministra obrony i wicepremiera ${ }^{79}$. Patrioci nie zaprzestali również proponować swoich projektów ograniczających prawa mniejszości. W czerwcu $2020 \mathrm{r}$.

74 В. Сидеров, Защо Борисов не попита за тракийските имоти в Анкара? в. „Атака”, 23.03.2012, https://tinyurl.com/y829ry3e; В. Сидеров: Ръководеният от Премянов Съюз на тракийските дружества е изияло в ръиете на БСП!, portal Фактор.бг, 26.03.2018, https://faktor.bg/bg/articles/siderov-rakovodeniyatot-premyanov-sayuz-na-trakiyskite-druzhestva-e-iztsyalo-v-ratsete-na-bsp, (dostęp: 22.06.2020).

${ }^{75}$ D. Mijatović, Country report: Commissioner for Human Rights of the Council of Europe. Report following her visit to Bulgaria from 25 to 29 November 2019, https://rm.coe.int/report-on-the-visit-to-bulgaria-from25-to-29-november-2019-by-dunja-m/16809cde16, (dostęp: 22.06.2020), s. 6-16.

${ }^{76}$ С. Колчакова, Джамбаски: Човеци с хормонални проблеми свързват ген. Лукова с нацизма, 15.02.2012, News.bg, https://news.bg/politics/dzhambazki-chovetsi-s-hormonalni-problemi-svarzvat-gen-lukov-s-natsizma. html, (dostęp: 22.06.2020).

77 3. Велинова, За първ път от години Луковмари не се състоя, 22.02.2020, БНТ1, https://bntnews. bg/bg/a/za-prv-pt-ot-godini-lukovmarsh-ne-se-sstoya, (dostęp: 22.06.2020).

${ }^{78}$ Н. Василева, Обединени патриоти продължават без Атака, 26.07.2019, БНТ1, https://bntnews. bg/bg/a/obedineni-patrioti-prodlzhavat-bez-ataka, (dostęp: 22.06.2020).

${ }^{79}$ В. Господинова, ВМРО и НФСБ изключиха АТАКА от Обединените патриоти, Капитал.бг, 25.07.2019, https://www.capital.bg/politika_i_ikonomika/bulgaria/2019/07/25/3943384_vmro_i_nfsb_izkljuchiha ataka_ot_obedinenite_patrioti/, (dostęp: $22 . \overline{0} 6.2020)$. 
wystąpili z wnioskiem, aby Komisja ds. przeciwdziałania dyskryminacji została zlikwidowana. W opinii OP quasi-sądowe uprawnienia KZD są szkodliwe i niepotrzebne, gdy w Bułgarii funkcjonuje wymiar sprawiedliwości. Tymczasem liczba zażaleń, które wpływają do komisji co roku, stale się zwiększa ${ }^{80}$. Jeżeli propozycja Patriotów spotka się z aprobatą SN, spełni się niebezpieczny precedens, który będzie oznaczał regres w rozwoju praw mniejszości etnicznych w Bułgarii.

Na podstawie dokonanej analizy programów trzech partii oraz retoryki prowadzonej przez ich czołowych aktywistów wyłania się stosunek tych podmiotów wobec mniejszości tureckiej w Bułgarii oraz sąsiedniej Turcji. Odwołując się ponownie do komponentów cechujących partie PRR, każdy z nich - autorytaryzm, populizm i natywizm - jest obecny w konteście ideologii, języka czy w konkretnych działaniach Patriotów. Autorytaryzm odnajdujemy w propozycjach mechanizmów prawnych ograniczających prawa mniejszości etnicznych. Za przykład tego można uznać plany referendum dot. wiadomości w języku tureckim (ATAKA) lub ideę limitowania prawa wyborczego cenzusem językowym (NFSB). Populizm wyłania się w wypowiedziach polityków OP. Język nienawiści, którym nierzadko operuja, pomaga wznosić podziały społeczne, wskazuje winnych złej sytuacji gospodarczej czy bezprawia. Widzimy to chociażby w wypowiedzi Simeonowa o Romach (NFSB) czy oskarżeniach padających pod adresem Ruchu na rzecz Praw i Swobód. W końcu motywy natywistyczne, utrwalone w każdym ze statutów partyjnych, odnalazły swoje miejsce w aktualnym programie rządu na lata 2017-2021. Troska o rozwój kultury bułgarskiej w kraju i za granicą, liczne cele integracyjne wokół jednolitego modelu dziedzictwa narodowego, niemal całkowicie wyparły uprzednio promowaną różnorodność etniczną i religijną. Natywizm i populizm cechują też charakter wypowiedzi o Republice Turcji. Kreowanie wizerunku sąsiedniego państwa jako największego zagrożenia suwerenności zwiększa szanse poparcia wśród najbardziej radykalnego elektoratu, nie rzutuje jednak pozytywnie na politykę zagraniczną państwa. Zwłaszcza gdy są to komentarze adresowane przez deputowanych obecnie urzędującego parlamentu.

Wrogie podejście wobec mniejszości tureckiej i Republiki Turcji jest atrybutem, na którym partie PRR nieustannie budują swój kapitał polityczny i rozwijają ideologiczną tożsamość. Obydwa elementy, postrzegane jako obce i niebezpieczne, w rzeczywistości stanowią gwarancję przetrwania dla ugrupowań tego $\mathrm{kreqgu}^{81}$. Działania populistycznej skrajnej prawicy skupiają się przede wszystkim na prowokacyjnej retoryce, często wzmocnionej ksenofobią i rasizmem, lecz rzadziej na realizacji konkretnych postulatów, co do których wciąż brak im szerszej aprobaty. To właśnie stanowi swoisty modus operandi tych podmiotów i definuje ich byt na bułgarskiej scenie politycznej.

\section{Bibliografia}

20 точки на партия АТАКА, Офицйален уебсайт на ПП АТАКА, https://web.archive.org/ web/20110508120244/http://www.ataka.bg/index.php?option=com_content\&task=view\&id=^ n13\&Itemid $=34$

\footnotetext{
${ }^{80}$ Патриотите искат закриване на Комисията за защиита от дискриминация, 03.06.2020, Официален уебсайт на ВМРО-БНД, https://tinyurl.com/ydh3tdj2, (dostęp: 22.06.2020).

${ }^{81}$ A. Todorov, The extreme right wing in Bulgaria, ,International Policy Analysis”, Berlin 2013, s. 3-7.
} 
Български хелзински комитет, Правата на човека в България през 2017, http:/www.bghelsinki. org/media/uploads/doklad2018.pdf

BAC, Решение но 636, 15.01.2019, http://www.sac.government.bg/court22.nsf/d6397429a 99ee2afc225661e00383a86/211a54167a5a1cb5c225837e0034a472?OpenDocument

Доган А., По образ и подобие на европейските измериния. Избрани речи на Ахмед Доган 1990-2008, Sofia 2009.

Мизов М., Българският етнически модел. Политическа митологема или проблемна реалност? Sofia 2011.

Основни цели на Национален Фронт за Спасение България, Офицйален уебсайт на НФСБ, http://www.nfsb.bg/targets.php

Програма на правителство на европейска интеграция, икономическия растеж и социялната отговорност 2005-2009, http://old.europe.bg/upload/docs/GovernmentalProgramme_final_ bg.pdf

Програма на правителството за стабилно развитие на Република България за периода 20142018 г., Sofia 2014, http://www.strategy.bg/StrategicDocuments/View.aspx?lang=bgBG\&Id $=\wedge n 950$

Програмна схема, Официален уебсайт на ПП АТАКА, https://web.archive.org/web/20070622175612/ http://www.ataka.bg/index.php?option=com_content\&task=view\&id=14\&Itemid=29

Програма на ВМРО-БНД, Официален уебсайт на ВМРО-БНД, www.vmro.bg/pages/документи/програма/

Програма за управление на правителството на Република България за периода 2017-2021 г., https://www.government.bg/files/common/GovPr_2017-2021.pdf

Решение за избиране на Министерски съвет на Република България, ДВ бр 37, 09.05.2017

Решение но 290, 25.05.2017 г., http://pris.government.bg/prin/document_view.aspx?DocumentID $=$ UJNEAox 1 U14dqwGAi3XoOw==

СГС, Регистър на политическите партии, https://sgs.justice.bg/bg/14755

Стенограми от пленарни заседания на 40-то Народно събрание, https:/parliament.bg/pg/plenaryst/ $\mathrm{ns} / 2 / \mathrm{ID} / 18$

Стенограми от пленарни заседания на 43-то Народно събрание, https://www.parliament.bg/bg/ plenaryst/ns/51/ID/5328

ЦИК, Решение но 80 от 11 май, 2005 г., http://pi2005.cik.bg/reshenia/080.html

ЦИК, Резултати от избори за президент и вицепрезидент на Републиката и Национален Референдум 2016, https://results.cik.bg/pvrnr2016/tur1/president/index.html

ЦИК, Резултатите от парламентарни избори 2005, http://pi2005.cik.bg/results/index.html

Устав на НФСБ, Официален уебсайт на НФСБ, http://www.nfsb.bg/public/documents/ustav_2017 edition.pdf

Brubaker R., Nacjonalizm inaczej. Struktura narodowa i kwestie narodowe w nowej Europie, Warszawa 1998.

Committee of ministers of Council of Europe, 13th Annual report of the Committee of Ministers. Supervision of the Execution of judgments and decisions of the European Court of Human Rights, Strasburg 2019, https://rm.coe.int/annual-report-2019/16809ec315

Cholakov P., Ethnic entrepreneurs unmasked, 2018.

ECHR, Annual report 2018, Strasburg 2018, https://www.echr.coe.int/Documents/Annual_report 2018_ENG.pdf

ECHR, Karaahmed vs. Bulgaria, App. 30587/13, http://hudoc.echr.coe.int/eng?i=001-152382

Frison-Roche F., Bulgarie: sociologie électorale d'Ataka, nouveau parti dans l'arène politique bulgare (2005), CERSA, https://www.colisee.org/old/public//article/fiche/1935

Ignazi P., The silent counter-revolution, „European Journal of Political Research”, 22, 2006.

Jackson Preece J., Prawa mniejszości, Warszawa 2007. 
Konstytucja Republiki Bułgarii 1991, Warszawa 2012, http://libr.sejm.gov.pl/tek01/txt/konst/ bulgaria2013.pdf

Mijatović D., Country report: Commissioner for Human Rights of the Council of Europe. Report following her visit to Bulgaria from 25 to 29 November 2019, https://rm.coe.int/report-on-thevisit-to-bulgaria-from-25-to-29-november-2019-by-dunja-m/16809cde16

Mudde C., The ideology of the extreme right, Manchester, 2002.

Mudde C., Populist radical right parties in Europe, Cambridge 2007.

Todorov A., The extreme right wing in Bulgaria, ,International Policy Analysis”, Berlin 2013.

Yanat Bagci Y., Bulgaria, my land, Al Jazeera, https://www.aljazeera.com/programmes/aljazeeraworld/2015/12/bulgaria-land-151215080838910.html

Oficjalna strona gazety „Ataka”

Oficjalna strona partii ВМРО-БНД

Portal БНТ.бг

Portal БНТ1.бг

Portal Фактор.бг

Portal Капитал.бг

Portal Новините.бг

Portal „Mediapool.bg”

Portal News.bg

Katarzyna Fijolek-Kwaśniewska, absolwentka stosunków międzynarodowych i bułgarystyki na Uniwersytecie Jagiellońskim. Doktorantka w Katedrze Historii Współczesnej Instytutu Nauk Politycznych i Stosunków Międzynarodowych UJ. Rozprawę doktorską pt. Polityka Bułgarii wobec mniejszości tureckiej po 1989 r. przygotowuje pod kierunkiem prof. Ireny Stawowy-Kawki. Jej zainteresowania badawcze koncentrują się wokół relacji państwo - grupy etniczne, problemów mniejszości muzułmańskich w Bułgarii oraz historii państw Europy Środkowo-Wschodniej. 